\title{
BROKERS AS FIDUCIARIES
}

\author{
Donald C. Langevoort ${ }^{*}$
}

The first formal legislative package sent to Congress by the Obama Administration dealing specifically with securities law reform was not about the financial crisis issues of derivatives, securitization, or credit ratings - though these came shortly thereafter. Instead, it was about consumer protection. ${ }^{1}$ Having proposed a bold new Consumer Financial Product Commission but chosen to leave investment product regulation in the jurisdiction of the SEC rather than shift it to the new agency, the Administration sought to enhance the consumer protection powers of the SEC so that they would be comparable with what the proposed new agency could do with respect to non-securities financial products. Substantively, the headline reform proposal was the authorization for the SEC to promulgate rules to conform the duties owed by broker-dealers to their customers with the duties owed by investment advisers to their clients, holding both to the same fiduciary standards of conduct. ${ }^{2}$

The fiduciary proposal touches on a long-standing and ongoing struggle in SEC policy-making arising out of the recognition that what brokers and investment advisers do in many instances is more similar than different. ${ }^{3} \mathrm{~A}$ study for the SEC by the RAND Corporation found, not surprisingly, that investors do not differentiate very well between advisory accounts and

\footnotetext{
* Thomas Aquinas Reynolds Professor of Law, Georgetown University Law Center. My thanks to Michael Holt for research assistance on this article.

1. See Press Release, Dep't of the Treasury, Fact Sheet: Administration's Regulatory Reform Agenda Moves Forward Legislation for Strengthening Investor Protection Delivered to Capitol Hill, No. TG-205 (July 10, 2009), available at http://www.ustreas.gov/press/releases/tg205.htm. The proposals were first articulated by the Treasury Department in its report entitled FinANCial Regulatory ReForm: ANeW FOUNDATION (May 2009), available at http://www.financialstability.gov/roadtostability/ regulatoryreform.html.

2. In December, 2009, the House of Representatives passed a financial services bill (H.R. 4173) that included a modified version of the Administration's proposal on conforming broker-dealer and investment adviser obligations. See House Passes Broad Legislation to Reform Financial Services Sector, 41 SEC. Reg. \& L. ReP. (BNA) 2253 (2009).

3. For other helpful discussions of this history, see Arthur B. Laby, Reforming the Regulation of Broker-Dealers and Investment Advisers, 65 Bus. LAw. 2 (forthcoming 2010); Barbara Black, Brokers and Advisers-What's In a Name?, 11 FordHAM J. CoRP. \& FIN. L. 31 (2005); see also sources cited infra note 10.
} 
brokerage accounts, and have very similar expectations out of both. ${ }^{4}$ Yet the statutory scheme draws a fairly blunt distinction. Broker-dealer regulation depends heavily on self-regulation, supplemented by SEC oversight. On matters such as sales practices, compensation arrangements and the like, the main rules are FINRA's, not the SEC's. Behind this was Congress' highly political judgment in the Maloney Act of 1938-which amended the Securities Exchange Act of 1934 to create a federal system of broker-dealer regulation - not to threaten or disturb the basic business model commonplace in the securities industry, ${ }^{5}$ which was about selling securities to customers in order to generate commission or markup revenue. Brokers have always offered advice, but usually in the context of selling products and services, and selling is not a fiduciary occupation.

On the other side of the line is the investment adviser, regulated under the Investment Advisers Act of 1940. There is no self-regulation here to which to defer, but the statutory and rule-based regulation is softer. It is easier to become an adviser than a broker-there are few serious qualification requirements, for example. However, largely because the Supreme Court said so in an early and influential decision, investment advisers are deemed fiduciaries vis-à-vis their clients, owing them duties of loyalty and care. ${ }^{6}$ This has been the clearest differentiation as a matter of law.

The blurring of the line between brokers and advisers is by now a familiar story. Until the early 1970's, fixed commission rates enforced by the stock exchanges limited competition in the brokerage industry, generating lucrative rents. The unfixing of commission rates in 1975 via Congressional and SEC mandate led to a rapid reduction in commission rates for executing trades because of aggressive competition and technological innovation, which in turn caused brokers to seek out alternative sources of income. (Many of the highprofile issues in securities regulation in the last thirty years, including the folding of retail brokerage into multi-service investment banking firms, the rise of proprietary trading, analyst conflicts of interest and the like, can all be traced back to this same history). Fee-based income was tempting, and by the mid-1990's many full-service brokerage firms - the big names in the industry-were experimenting with wrap-accounts and other fee-based

4. See RAND Corp., Investor And Industry Perspectives on Investment Advisers and Broker-DeAlers REPORT (2008), available at http://www.sec.gov/news/press/2008/2008-1_ randiabdreport.pdf.

5. See Joel Seligman, The Transformation of Wall Street 188-89 (3d ed. 2003).

6. SEC v. Capital Gains Res. Bureau, Inc., 375 U.S. 180, 191 (1963). 
arrangements for customers with significant investment portfolios. ${ }^{7}$ The legal question was whether, in so doing, they became investment advisers as well as brokers. According to statute, not if the advice was "solely incidental" to their brokerage activities (thereby triggering an exemption from the Advisers Act), but the meaning of that phrase is far from self-evident. The SEC did the brokerage industry something of a favor by adopting a rule construing the "solely incidental" language broadly, albeit at the price of some additional regulatory conditions, ${ }^{8}$ but the D.C. Circuit was unimpressed and struck down the rule in 2007. ${ }^{9}$ The confusion was thus reinstated. Resolving it was on the verge of being a top agenda item for the SEC when the financial crisis intervened and the Commission had more pressing things to worry about, including its own viability and future.

The Administration's July 2009 proposal goes to the substantive heart of the contest by seeking convergence in the rules by which brokers and advisers must live when they interact with customers and clients. The goal is to extend the fiduciary treatment that advisers have long had to live with to brokers as well. Of course, this proposal might not become law, or it might be changed significantly in the meantime if it does. But the history just described shows that the issue should be addressed even if no legislation passes - the brokeradviser dividing line simply becomes more and more untenable, with the problem exacerbated as brokerage firms work that much more creatively to offset the loss of transaction-based revenue brought on by the current crisis. And if popular distrust of Wall Street persists through a prolonged economic slowdown, the brokerage industry will have a hard time resisting stricter conduct regulation.

So in this essay, I want to think through what it would-and should - mean for the SEC to take up this agenda, whether prompted by statutory reform or simply on its own using existing statutory authority. ${ }^{10}$ At

7. See Certain Broker-Dealers Deemed Not to Be Investment Advisors, Exchange Act Release No. 51523, [2005 Transfer Binder] Fed. Sec. L. Rep. (CCH) 81,925, at 81,929-931 (Apr. 7, 2005).

8. Rule 202(a)(11)-1, adopted in Certain Broker-Dealers Deemed Not to Be Investment Advisors, supra note 7.

9. Fin. Planning Ass'n v. SEC, 482 F.3d 481 (D.C. Cir. 2007). See also Thomas v. Metro. Life Ins. Co., Fed Sec. L. Rep. (CCH) 995,344 (W.D. Okla. 2009) (finding the solely incidental standard applicable).

10. Three recent discussions are along similar lines to mine: One is a thoughtful discussion by Elisse Walter, Comm'r, U.S. Sec. and Exch. Comm'n, Regulating Broker-Dealers and Investment Advisers: Demarcation or Harmonization? (May 5, 2009), available at http://www.sec.gov/news/speech/2009/ spch050509ebw.htm. (For the somewhat different but also thoughtful views of Commissioner Luis Aguilar, see Luis Aguilar, U.S. Sec. and Exch. Comm'n, SEC's Oversight of the Adviser Industry Bolsters Investor Protection (May 7, 2009) available at http://www.sec.gov/news/speech/2009/spch050709laa.htm.) The 
the risk of sounding the trite, the Commission will be heading into a swamp (or thicket, morass, etc.) and will find very few solutions that are easy or comfortable. At bottom, the fiduciary label just does not fit a sales-based industry very well. But some seventy years of SEC regulation, self-regulation, and judicial decisions have been working hard to try to turn the brokerage industry into something better than the retail mattress or shoe business. The success has been mixed, at best, but there is a foundation on which to build. To be clear, then, I favor undertaking this effort and hope it becomes the SEC's whether or not the legislation passes, so long as the fiduciary rhetoric is not read to create a straight-jacket. To recognize the continued separation of the brokerage and advisory industries is an implicit acknowledgment that there are differences between them, which need to be kept in mind in seeking harmonization of the advisory and sales practice rules. The goal is better conduct out of the industry than we have seen recently, not technical consistency. ${ }^{11}$

\section{The Depth of the Duty: "But to say that a man is a fiduciary ONLY BEGINS INQUIRY...."}

These oft-repeated words ${ }^{12}$ capture the dominant scholarly view today that the fiduciary concept is horribly indeterminate-more a label or conclusion than a useful intellectual framework. Fiduciary rhetoric is the law's way of saying that there are relationships where one party so depends on another that duties of loyalty, care and candor ought be imposed, but simply using words like dependency (or superiority, dominance, control, etc.) rarely suffices to define those duties except in the most abstract way. The problem is that most fiduciary relationships arise within contractual ones ${ }^{13}$-a person

second is Tamar Frankel, Fiduciary Duties of Broker-Advisers-Financial Planners and Money Managers (Boston Univ. Sch. of Law, Working Paper No. 09-36, 2009), available at www.ssrn.com/abstracts= 1446750. See also Laby, supra note 3. Even though the Securities Exchange Act does not give the SEC plenary regulatory authority to set conduct standards for broker-dealers, it does have potent tools at its disposal. Most notably, Section 19(c) gives to the SEC the ability to amend the conduct rules of FINRA and other self-regulatory organizations on its own. In addition, Section 15(c)(2)(D) of the Act gives the SEC the power to adopt rules to define "and prescribe means reasonably designed to prevent" broker-dealer fraud in the over the counter markets. For comments on the Chairman and CEO of FINRA on the subject, see Rick Ketchum, Chairman and CEO, FINRA, Remarks to the SIFMA Annual Meeting (Oct. 27, 2009), available at http://events.sifma.org/uploadedFiles/Events/2009/annual/Ketchum-speech.pdf.

11. See Walter, supra note 10.

12. SEC v. Chenery Corp., 318 U.S. 80, 85 (1943) (Frankfurter, J., plurality opinion).

13. See Robert Cooter, The Fiduciary Relationship: Its Economic Character and Legal Consequences, 66 N.Y.U. L. REV. 1045, 1067 (1991). 
hires an attorney, investment adviser, etc. to perform a service and thereby satisfy certain needs, or multiple investors pool their money in some kind of joint venture. Because of the contractual relationship, the parties are presumably free to define and limit the scope of the duties owed to fit their particular needs, which they may do either explicitly or implicitly. Seen through that lens, defining the precise content of a fiduciary's responsibility is just a form of contract interpretation, and notions like disclosure and consent can freely be invoked to override any presumed background norms. Taken to its logical conclusion, fiduciary duty becomes entirely contractual - hence the contractarian move in corporate law, ${ }^{14}$ the complete disappearance of a mandatory fiduciary obligation in some states' limited liability company law, and so forth. That reductionism troubles many courts and commentators, however, and so the fiduciary label retains some independent significance. ${ }^{15}$ But how and to what extent are left largely unspecified, ${ }^{16}$ especially when the customer is reasonably sophisticated.

That has been so with respect to stockbrokers' duties, too. A broker does have a fiduciary-like duty of best execution of a trade (though even that duty has been quite difficult to define) ${ }^{17}$ but in most states' law there is no comparable duty inherent in the relationship itself unless the broker somehow controls the account. The broker controls a discretionary account, to be sure. As to non-discretionary accounts, on the other hand, the state law is inconsistent, but a common view is that the relationship is not fiduciary unless the broker either explicitly consents to advisory status or otherwise effectively directs the customer's trading-which is not so in most cases. ${ }^{18}$

Why is this area of law so confusing? After all, broker-customer relationships are frequently characterized by a high degree of trust, which naturally suggests dependency. But this is not always true (e.g., brokerage firms that specialize in cold-calling, or online firms that offer little in the way of customized advice), so that it is difficult to make any categorical claims

\footnotetext{
14. For a discussion of this long-standing debate, see Kelli Alces, Debunking the Corporate Fiduciary Myth, 35 J. CORP. L. (forthcoming 2009).

15. E.g., Tamar Frankel, Fiduciary Duties as Default Rules, 74 Or. L. Rev. 1209 (1995).

16. See Deborah DeMott, Beyond Metaphor: An Analysis of Fiduciary Obligation, 1988 Duke L.J. 879

17. See E.F. Hutton \& Co., [1988-89 Transfer Binder] Fed. Sec. L. Rep. (CCH) ๆ 84,303 (SEC Admin. Proc. July 6, 1988); Newton v. Merrill Lynch, Pierce, Fenner \& Smith, Inc., 135 F.3d 267 (3d Cir. 1998) (en banc).

18. E.g., Geman v. SEC, 334 F.3d 1183 (10th Cir. 2003); De Kwiatkowski v. Bear, Stearns \& Co., 306 F.3d 1293 (2d Cir. 2002) (applying New York law); Paine, Webber, Jackson \& Curtis, Inc. v. Adams, 718 P.2d 508 (Colo. 1986).
} 
about a broker's status. And even when there is some degree of trust, the broker's customer is supposedly on notice that a brokerage firm is a sales operation - that is how the business has always been organized, and the tacit legislative approval of the combination of broker and dealer functions in a single firm recognizes and accepts the inevitable conflict that results. ${ }^{19}$ If so, the customer should understand that there is a self-interested motive behind the broker's friendly demeanor, and act with caution comparable to other situations - auto and home repairs, computer sales, and so forth - where there may also be a high degree of dependency and trust by the consumer but usually no legal "fiduciarization" of the relationship.

For the most part, the law has reacted to this muddle with avoidance strategies. In litigation, the SEC has persuaded many courts that brokers make an implied representation of fair dealing (the so-called shingle theory) whether or not they are fiduciaries, which has sufficed to reach the most troublesome sales practices by making them fraudulent. ${ }^{20}$ And FINRA's (earlier, the NASD's) rules prohibit a wide variety of unethical conduct, again without regard to fiduciary status. In arbitration-the typical location for the resolution of broker-customer disputes - claimants readily have these at their disposal as well as a variety of other contractual theories, making a fiduciary breach claim unessential in most cases claiming abuse.

So what would be gained by making brokers fiduciaries with respect to their advisory activities? Fundamentally, there are two main concerns with broker sales practices. ${ }^{21}$ One is the recommendation and sale of products that are more risky than the customer suspects, so that the customer misunderstands the risk/return trade-off. Fortunately, this is an area that is quite thoroughly addressed by the SEC and FINRA: suitability rules and "know your security" standards are designed to prevent brokers from pushing speculative or risky stocks where the customer wants and expects

19. See Seligman, supra note 5 .

20. See Charles Hughes \& Co. v. SEC, 139 F.2d 434 (2d Cir. 1943); Norman S. Poser \& James A. Fanto, Broker-Dealer Law and Regulation (4th ed. 2009). While this body of law still has ample case law support, it is built on a fragile conceptual basis, because the implied representation is something of a fiction. See Roberta S. Karmel, Is the Shingle Theory Dead?, 52 WASH. \& LeE L. REV. 1271 (1995).

21. One other concern has to do with the broker's obligation to intervene when a customer decides on his or her own to undertake a risky trading strategy. Absent fiduciary characterization, the basis for a duty to warn in the absence of any recommendation is weak. For discussions of this problem, see Frederick M. Gedicks, Suitability Claims and Purchases of Unrecommended Securities: An Agency Theory of Broker-Dealer Liability, 37 ARIz. ST. L.J. 535 (2005); Barbara Black \& Jill I. Gross, Economic Suicide: The Collision of Ethics and Risk in Securities Law, 64 U. PitT. L. Rev. 483 (2003). 
conservatism. ${ }^{22}$ This is buttressed by fairly expansive disclosure obligations that courts have imposed on brokers even in the absence of a fiduciary relationship, including the affirmative obligation to disclose hidden risk factors that are necessary to evaluate the transaction being recommended. ${ }^{23}$

The other - and much more contentious - problem is the recommendation and sale of products that are too costly given what the customer wants. Here again, there are significant regulatory efforts - for instance, the regulation of dealer markups, and a substantial (if not entirely successful) effort to force disclosure of costs and other conflict-of-interest related information. ${ }^{24}$ But ultimately, this is where we see the clearest gap between advisers and brokers. An adviser is presumably expected to recommend the best available securities for the desired portfolio, taking costs into account. By contrast, a broker has no well-defined obligation to offer the best available securities- just suitable ones with no hidden risks or fees. Within these norms, the broker is free to push what is in inventory, or what is otherwise most profitable to sell, even if there may be other, less costly investments that would satisfy the customers risk/return preferences just as well or better. In other words, the broker can recommend a high-load mutual fund to a customer without revealing that Vanguard has a comparable product in terms of expected market returns that costs substantially less.

The historic tolerance of this "fiduciary gap" with respect to costs and fees is understandable. We could simply be cynical, of course: pushing excessively costly investment strategies is profitable for the industry, and it expends political resources to protect those profits. Bolstering this is the background norm in American society that tolerates profit-seeking behavior in most industries; to fiduciarize the sale of investment products prompts the question of why we do not even think about doing the same in so many other areas where consumers are also at risk of overpaying. But there is also a basic economics point. Except in the true fee-based account, commissions and markups pay for the advice customers receive. If that revenue stream is threatened, one would expect that more and more customers would be frozen out of any but the most low-cost brokerage services.

22. FINRA has recently undertaken to revise and codify its standards in this area. See Regulatory Notice 09-25 (May 2009).

23. See Leib v. Merrill Lynch, Pierce, Fenner \& Smith, Inc., 461 F. Supp. 951, 953 (E.D. Mich. 1978). For a more recent decision situating the duty to disclose in the half truth doctrine, see In re Credit Suisse First Boston Corp. Sec. Litig., [1998 Transfer Binder] Fed. Sec. L. Rep. (CCH) ๆ 90,306 (S.D.N.Y. 1998).

24. E.g., Chasins v. Smith, Barney \& Co., 438 F.2d 1167 (2d Cir. 1970). 
As a result, policy has been something of a muddle - restraints on the most offensive revenue-generating strategies, but substantial tolerance of aggressive profit-seeking behavior that stays short of the line. Even though there are significant disclosure obligations, they are not comprehensive, and the cases are somewhat unpredictable, especially on matters such as broker compensation arrangements. ${ }^{25}$ This is particularly well illustrated by the incoherence of the law on whether brokers must disclose "shelf space" arrangements with mutual fund managers who pay to be featured: federal and state regulators have brought and settled numerous such cases, while the courts have expressed skepticism over whether there is any such duty to disclose. ${ }^{26}$

Here we find the SEC's initial agenda item if it wishes to make brokers act more fiduciary-like. One important step toward more fiduciary-like status would be to assure that what is truly significant in deciding whether to follow a broker's advice should always be revealed in a timely and effective manner, including conflicts of interest that are out of ordinary expectation. The key to such disclosure is effectiveness, not boilerplate: the SEC needs to assess whether the disclosure actually communicates the desired substance to the customer. The Administration's legislative proposal supplements this by saying that the Commission should use sophisticated social science tools and strategies drawn from consumer psychology and behavioral economics to assess and improve disclosure effectiveness. The presumption is that ineffective disclosure equals no disclosure; it negates any consent that would otherwise free the broker from strict fiduciary expectations.

What we know about consumer psychology suggests the extent of the challenge in this. ${ }^{27}$ Take, for example, what might seem to be an example

25. See United States v. Skelly, 442 F.3d 94, 97 (2d Cir. 2006) (“[N]o SEC rule requires the registered representatives who deal with the customers to disclose their own compensation, whether pegged to a particular trade or otherwise."); United States v. Alvarado, 2001 WL 1631396, *8 (S.D.N.Y. 2001) ("Neither the SEC nor NASD have required registered representatives of broker/dealers to disclose their own compensation in a securities transaction, although both have been fully aware that registered representatives often received special incentives beyond the normal compensation to sell a particular product."); Shivangi v. Dean Witter Reynolds, 825 F.2d 885 (5th Cir. 1987).

26. Compare In re Edward Jones \& Co., Admin. Proc. 3-11780, Dec. 22, 2004 (joint action by SEC, the NASD, and the NYSE), with Hoffman v. UBS-AG, 591 F. Supp. 2d 522 (S.D.N.Y. 2008). FINRA intends to fill this gap. See FINRA Notice 09-34, June 2009, available at http://www.finra.org/ web/groups/industry/@ip/@reg/@notice/documents/notices/p119013.pdf (last visited Feb. 16, 2010).

27. See Donald C. Langevoort, Selling Hope, Selling Risk: Some Lessons for Law from Behavioral Economics About Stockbrokers and Sophisticated Customers, 84 CAL. L. REv. 627 (1996) [hereinafter Langevoort, Selling Hope]; see also Troy A. Paredes, Blinded by the Light: Information Overload and its Consequences for Securities Regulation, 81 WASH. U. L.Q. 417 (2003); Jeff Schwartz, Reconceptualizing 
where the SEC did exactly what was expected - the recent effort to use the summary prospectus for mutual fund sales, featuring an easily accessible set of the most important data, in place of the full prospectus. A study by Beshears, Choi, Laibson and Madrian examined experimentally how a reasonably well-educated group of investors - white-collar staff at Harvard University - used various disclosure vehicles in making portfolio allocation decisions. ${ }^{28}$ Users of the summary prospectus did no better or worse than users of the full prospectus, which represents some gain because the summary prospectus users spent less time doing just as well at the task. The bad news, however, is that the subjects still made surprisingly poor allocation decisions on average when it came to managing costs.

The initial challenge is overcoming low sophistication in how to process important information. But Beshears et al. simply compared the use of summary versus full prospectuses, without the promoters of the products using sales and marketing strategies to try to influence choices - something they do quite aggressively and effectively in the field. ${ }^{29}$ The larger challenge of any disclosure-oriented strategy to manage fiduciary conflicts is overcoming the sales efforts, whether via the media or - probably more powerfully - through the interpersonal skills of sales people trained (and highly motivated) to elicit trusting responses from their customers. ${ }^{30}$

The hard question for the SEC will be how hard to push against the potency of salesmanship in the broker-customer setting. ${ }^{31}$ The Administration's proposal seems to recognize the problem by authorizing the Commission to engaged in substantive regulation-banning sales practices, compensation arrangements and conflicts of interest—where disclosure may

Investment Management Regulation, 16 Geo. Mason L. Rev. 521 (2009); Lauren Willis, Against Financial Literacy Education, 94 Iowa L. Rev. 197 (2008).

28. John Beshears et al., How Does Simplified Disclosure Affect Individuals' Mutual Fund Choices?, (NBER Working Paper 14859, April 2009), available at www.nber.org/papers/w14859.

29. E.g., Michael J. Cooper et al., Changing Names with Style: Mutual Fund Name Changes and their Effects on Fund Flows, 60 J. Fin. 2825 (2005); Prem C. Jain \& Joanna Shuang Wu, Truth in Mutual Fund Advertising: Evidence on Future Performance and Fund Flows, 55 J. Fin. 937 (2000).

30. There is some psychological evidence to suggest that simply disclosing a conflict of interest may prompt more opportunism by the conflicted party and greater trust by the trusting party (the latter, presumably, because the trusting party considers the disclosure an act of candor). See Daylian Cain et al., The Dirt on Coming Clean: Perverse Effects of Disclosing Conflicts of Interest, 34 J. Legal Stud. 1 (2005). Whether this effect is truly robust in settings where consumers have the ability to sanction agents who overreach has been questioned. See Bryan Church \& Xi (Jason) Kuang, Conflicts of Interest, Disclosure and (Costly) Sanctions: Experimental Evidence, 38 J. Leg. STUd. 505 (2009).

31. See Donald C. Langevoort, The SEC, Retail Investors, and the Institutionalization of the Securities Markets, 95 VA. L. REV. 1025, 1048-55 (2009). 
not suffice, but that can be powerfully disruptive and hence politically dangerous. A good example would be broker-sold mutual fund shares. There is evidence that investors pay significantly more for mutual fund investments sold via the broker channel, without receiving any better fund performance. ${ }^{32}$ The conflicts of interest here are clear enough — brokers are tempted to push high load shares, shares of funds that pay for "shelf space" (i.e., featured presence in brokers' recommendations) or of proprietary funds sponsored by the broker's firm, which are naturally more profitable for the firm. ${ }^{33}$

There are various reasons to doubt how well simple disclosure might address this. Loads themselves are fully disclosed (and the proprietary funds are marketed based on the name recognition); litigation has forced greater disclosure of both internal and third-party compensation arrangements as well, although there is some judicial resistance here. To be sure, there may be better disclosure strategies to try, including greater emphasis on comparative fees. ${ }^{34}$ But this is an area, probably, where savvy salesmanship typically triumphs over written content. ${ }^{35}$

The question, then, is whether to resort to the other authority, to regulate more substantively. But this is difficult because as currently structured, the extra expenses built into the load or related distribution fee arrangement are the compensation for the broker's efforts, which may have value apart from the performance of the fund. The broker may spend time helping the customer with general asset allocation advice, basic financial education, or in explaining why mutual funds generally might be better investments that costly banksponsored programs or insurance products. Of course, some (perhaps a lot) of the time there is little or no added value: the broker is simply pushing an inferior product on unsophisticated investors, who assume that what is recommended is a good choice. Differentiating between the situations is impossible ex ante, however, and requiring the broker to recommend comparable but lower cost funds is both hard to enforce, and if effective, would simply force the better brokers to seek an alternative form of compensation.

\footnotetext{
32. See Daniel Bergstresser et al., Assessing the Costs and Benefits of Brokers in the Mutual Fund Industry, 22 ReV. Fin. STUD. 4129 (2009).

33. See supra note 26.

34. See James D. Cox \& John W. Payne, Mutual Fund Expense Disclosures: A Behavioral Perspective, 83 WASH. U. L.Q. 907 (2005).

35. For an expression of doubt about the efficacy of disclosure of differential commissions in the insurance industry, see Daniel Schwarcz, Beyond Disclosure: The Case for Banning Contingent Commissions, 25 Yale L. \& Pol’y Rev. 289 (2007).
} 
To be most potent, then, reform would have to be structural to make brokers into fiduciaries: turn broker-customer dealings to a solely fee-based relationship, with a prohibition on any incentives apart from those based on the customer's (now client's) financial success. In essence, this would require a segregation of the broker function from the dealer function, via a "Chinese Wall" that would have to be watched constantly and very carefully for cracks and leaks. The broker, in other words, becomes solely an investment adviser, with the ability to execute trades.

Whether this degree of structural reform would really benefit investors is not entirely clear (sufficiently gullible investors would end up paying too much in advisory fees, unless those, too, were regulated), and it would be hard to police. In some ways - albeit on a smaller scale - a similar segregation has been tried with respect to investment analysts as a result of the conflicts of interests they faced in making recommendations, and a main effect has been that brokerage firms now employ fewer analysts, meaning a reduction in the amount of analyst coverage especially for emerging and mid-size issuers. ${ }^{36}$

I doubt that the case has been made for such radical structural reform, and so suspect that the SEC would ultimately decide not to alter so completely the sales-based nature of the brokerage business. That means, however, relaxing somewhat the fiduciary expectation and regulating more at the margins. Disclosure options could be explored more carefully, and sales incentives could be regulated to take away the most obvious pressures-differential commissions that cannot be justified in terms of the effort necessary to sell the product knowledgeably and responsibly, for example. Firms might be asked for formulate broker compensation plans designed to promote fiduciary-like behavior, subject to SEC and FINRA inspection, approval and monitoring, with material departures from the letter or spirit being a significant regulatory violation. Because the conflicts do not go away entirely, however, we should not expect more moderate steps to resolve the fiduciary problem. At most, it manages it better.

If this is the likely outcome, it does not really require new legislation - though the clarifications in authority may be helpful. FINRA, at least, could impose both disclosure and substantive rules under its authority to implement and enforce the just and equitable principles of the trade (and the SEC has statutory authority to force FINRA's rule-making to take

36. Jill Fisch, Does Analyst Independence Sell Investors Short?, 55 UCLA L. REv. 39 (2007); Andrew Boni \& Kent Womack, Wall Street Research: Will New Rules Change its Usefulness?, 59 Fin. Analysts J., No. 3, May/June 2003, at 25. 
whatever turn it wants ${ }^{37}$ ). The not-so-subtle message in the Administration's July 2009 proposal goes more to who regulates than what the regulation looks like. For some seventy years, the presumption has been that the industry asserts its own vision of what constitutes just and equitable principles, which have reflected a conservative (and sometimes self-serving) view of what the underlying trade really is. By and large, the SEC has respected that presumption, even though it could choose to act more aggressively. By contrast, the proposed legislation clearly assigns to the SEC plenary power over defining that trade, and the ethics that go with it. Were that shift in primary authority ever to take place - either on the SEC's own motion or because a new statute forces its hand - it would be a remarkable change.

\section{The Breadth of the Duty: Institutions and "Sophisticated" or WEALThy Individuals}

We know that, for the most part, the current financial crisis was initially triggered by weaknesses in the home (mainly subprime) mortgage market that swiftly caused a drop in the value of seemingly safe mortgage backed securities and derivatives based on those securities. And the marketplace for securitized debt and derivatives is largely institutional, not retail. One of the most profound questions for securities regulation going forward is why-assuming that at least some of this severe risk was foreseeable - institutions were such willing buyers of so much of that debt. The simple answer offered by many goes to credit ratings: buyers simply assumed that the high-quality ratings reflected expert assessment of the absence of such risk. The credit rating agencies, whether driven by conflicts of interest or a lack of sufficient information and expertise, assigned excessively high ratings. The buyers relied on that.

The real story is probably much more complicated. Many institutional buyers were well aware of the conflicts of interest and difficulty of evaluating risk in these extraordinarily complex products, but bought anyway. Some had on their staffs former credit rating analysts. Moreover, the so-called warning signs about excessive risk were largely in the public domain: the grounds for concern visible to any sufficiently sophisticated and interested analyst.

How then to explain the strong appetite for these securities? To me, answering this question is a crucial task for the SEC, because no sensible regulatory reform can be devised without it. One possibility is perceptual. The 
risk of a severe drop in the value of these securities, while not nil, was treated as sufficiently low that it led to no aversion. In other words, our current recognition of the risk is a product of hindsight-back then, perfectly reasonable investors treated any expression of concern as momentary emotion, like wondering if the plane might crash just before takeoff. Risk is a social construct, based on social proof. On reflection, the sophisticated market on both the buy- and sell-side simply was no afraid until much too late.

A second is a variation on this, and neatly captured (with reference to the sell-side) by Citigroup's Chuck Prince, who famously commented in July 2007, "[w]hen the music stops, in terms of liquidity, things will get complicated. But as long as the music is playing, you've got to get up and dance. We're still dancing." ${ }^{\prime 38}$ That is, the perceived risk was palpable but market participants took no evasive action because of a felt need to compete and not leave any money lying on the table. The major participants were unwilling to sacrifice fees or yields by backing off or hedging aggressively if that would trigger a short-term competitive penalty in either the stock market or the market for investment talent because of diminished profitability - something like the game of chicken. Studies of the tech stock bubble give ample evidence of the power of competition to prompt excessive risk-taking by institutional buyers. ${ }^{39}$ The economics and psychology (perhaps even neuroeconomics ${ }^{40}$ ) behind this are not fully understood but deserve very careful study.

Both of these possibilities suggest that the information and incentives on both the buy- and sell-side were largely symmetric, so that they do not necessarily suggest any abuse of buyers by sellers. A third possibility, however, is that the sell-side did have a greater awareness of the risk associated with these products - or possessed information that put them into a position know about the risk - and aggressively sought to transfer that risk to unsuspecting institutional buyers. As noted above, this is hard to believe at the high end of buyer sophistication. The smart buyers might not have the same information as the sellers, but were aware of their disadvantage and the risk that arose as a result. But the institutional buyer market is very diverse,

38. See Wall Street's bruising musical chairs, http://blogs.ft.com/gapperblog/2007/11/wallstreets-brhtml (Nov. 15, 2007) (comment to the Financial Times).

39. See Markus Brunnermeier \& Stefan Nagel, Hedge Funds and the Technology Bubble, 59 J. Fin. 2013 (2004).

40. See Andrew Lo, Hedge Funds, Systemic Risk and the Financial Crisis of 2007-08, available at http://papers.ssrn.com/sol3/papers.cfm?abstract_id=1301217; Andrew Lo et al., Fear and Greed in the Financial Markets: An Online Clinical Study, 95 Am. Econ. Rev. 352 (2005). 
and stories from the financial crisis frequently tell of lower end institutions - small city or township pension funds, for example - who were easy prey for salespeople from securities firms peddling exotic debt instruments and derivatives.

This brings us back to the fiduciary question. An important task if the SEC decides to create greater convergence as between brokers and investment advisers is defining its scope. The trigger for the litigation over the separate treatment of brokers and advisers were wrap-fee and similar arrangements, characterized by a formal account relationship with the brokerage firm. The fee was for the services surrounding the account, including advice, very much like the formal contractual relationship between an adviser and client. The Commission could, then, take fee-based advisory arrangements as defining the scope of convergence, which would largely limit it to the retail setting.

But the fiduciary duty problem extends more broadly; even FINRA's just and equitable principles of the trade explicitly apply to institutional sales practices as well as retail. ${ }^{41}$ One risk in limiting the fiduciary duty to retail feebased accounts is the negative implication that outside of it, a lower standard applies. The Administration's proposal would give the SEC the flexibility to regulate the provision of investment advice to create fiduciary-like duties to retail customers "or such other customers or clients as the Commission may by rule provide." And nothing in the grant of authority limits it to formal, feebased advisory relationships. Hence, the Commission - whether under current law or armed with new statutory powers - can address the problem of information asymmetry in the institutional sales context, assuming the broker is providing investment advice or recommendations.

What constitutes providing advice? FINRA has a long history of basing its sales-practice rules (e.g., suitability and "know your security") on the making of recommendations, and has applied these norms fairly rigorously in the context of institutional sales. There is probably good reason to provide at least an expansive fiduciary-like duty of disclosure in any institutional setting based on a relationship where the seller invites reliance on its superior skill and knowledge in understanding and evaluating investment products of the sort being sold.

41. See NASD IM-2310-3, approved by the SEC pursuant to Exchange Act Rel. No., 36921, Mar. 14, 1996 (proposed to be codified pursuant to FINRA Regulatory Notice 09-25 (May 2009)). The institution can waive this upon satisfaction of certain conditions. On the debate over this issue, see Norman Poser, Liability of Broker-Dealers for Unsuitable Recommendations to Institutional Investors, 2001 BYU. L. Rev. 1493; Langevoort, Selling Hope, supra note 27; Jerry Markham, Protecting the Institutional Investor-Jungle Predator or Shorn Lamb?, 12 YALE J. Reg. 345 (1995). 
This would be quite important because the case law in this area has taken some distinctly anti-investor turns. A good example is Banca Cremi S.A. v. Alex. Brown \& Sons, Inc., ${ }^{42}$ which dealt with the sale of mortgage-backed securities (from the risky tranche known as "inverse floaters") to a Mexican commercial bank. The court held that the presence of basic investment sophistication on the part of bank personnel took away its right to rely on any representations made during the selling process, so that even if the Brown salespeople actively misrepresented the riskiness of the securities, there could be no recovery. To be sure, the court said that this was a facts and circumstances analysis, and did not say that institutional investors never have a right to rely. But the facts and circumstances of the case at hand seemed very much to be one where there was asymmetric information and skill, making the relationship ripe for abuse if judicial protection disappears. This is an area where the SEC could be constructive by refashioning the legal character of the relationship in those situations where trust is invited and likely; fiduciary-like relationships naturally invite justifiable reliance. ${ }^{43}$

Thus far in our discussion of fiduciary duties, we have been focusing on the obligations of candor and loyalty. In the case of sales of excessively risky asset-backed securities, as we have noted, a question arises as to what contemporaneous appreciation the sellers had of the risk. That takes to the duty of care: what obligation do brokers have to inquire into the complexities of the packaged instruments and come to an independent assessment of risk and other material features, so that they can discharge their disclosure responsibilities effectively?

In the broker-dealer area, this has been addressed by the "know your security" obligation, the implied representation that a recommendation has in fact been researched. ${ }^{44}$ But this is not a body of case law that is particularly well developed, and has been truncated in private litigation by the fact that customers must show a deliberate or reckless failure to investigate, ${ }^{45}$ which limits its use to fairly egregious cases. Rather, the stress has been on the public/private character of the securities being sold. Where (as with securitized debt instruments) the offerings are essentially of new securities

42. 132 F.3d 1017 (4th Cir. 1997).

43. Professor Frankel argues that "sales talk" should be subject to fiduciary duties. See Frankel, supra note 10 , at 16 .

44. See Hanly v. SEC, 415 F.2d 589 (2d Cir. 1969); James D. Cox et al., Securities Regulation: CASes And Materials 1034-35 (6th ed. 2009).

45. See MacDonald v. Alan Bush Brokerage Co., 863 F.2d 809 (11 th Cir. 1989). Like so many other areas of broker-dealer liability law, the trend toward mandatory arbitration also truncates the doctrinal guidance that judicial decisions provide. 
each time a portfolio is packaged, the offerings must be registered with the SEC unless an exemption is available. If registered, section 11 creates a potent mix of strict and due diligence liability for issuers and underwriters that should have the effect of prompting inquiry. As a matter of practice because these are typically done as shelf takedowns, diligence has not always happened, but - assuming that the WorldCom case is right ${ }^{46}$ - liability follows fairly readily because speed of distribution is no excuse for lack of inquiry. Whether the high credit ratings assigned these securities is a reason to relax the due diligence obligation remains to be litigated; given the doubts about the integrity of those ratings (and the private knowledge allegedly possessed by the underwriters about the underlying risk) I would think not.

Sales to institutional investors, however, can be structured as exempt private offerings, and the resale market-something strongly desired even though it is not terribly liquid-is improving because of technological innovation. I suspect that a noticeable increase in the liability threat for publicly registered asset-backed securities would simply shift more effort in the direction of privately-structured sales. Here, there has been no federallymandated due diligence obligation ever since the Supreme Court's Gustafson decision. ${ }^{47}$ The Obama Administration had recommended an overturning of Gustafson, though this was not in the legislative reform package sent to Congress.

Pending greater clarity in litigation standards, the SEC should give serious thought to a better specified "know your security" rule as part of the project of bringing brokers closer to being fiduciaries. How precisely to handle the credit ratings issue is well beyond my subject here, but conclusive deference - that any highly-rated security can be recommended as safe without further thought or inquiry — is plainly unwarranted.

\section{Framing the Obligations}

The message from the foregoing discussion is that applying fiduciary-like duties to brokers is more complicated that it might seem. Thus a big question for the SEC is how specific to be: should there be an extensive set of "fair practice" rules that seek to describe those obligations, or should the

46. In re Worldcom Inc. Sec. Litig., 346 F. Supp. 2d 628 (S.D.N.Y. 2004) (rejecting argument that shelf registration due diligence is limited to what is practicable within a short amount of time).

47. Gustafson v. Alloyd Corp., 513 U.S. 561 (1994) (effectively limiting scope of section 12(a)(2) - a negligence-based cause of action for sales of securities via false or misleading prospectuses and oral communications - to public offerings). 
Commission instead simply articulate a broad principle-e.g., "In offering advice to their customers or clients, broker-dealers and investment advisers shall act with the utmost loyalty, candor and care"-and leave to arbitration, litigation, and enforcement actions the fleshing out of what this might mean?

We should note at the outset that any such SEC rule almost certainly would not create an implied private right of action, at least directly. Enforcement would be mainly for the Commission and the SROs. At first glance, this would seem to reduce the scope of the uncertainty problem. But in arbitrations especially, and even in litigation, there are backdoor ways of invoking SEC rules - for instance, claiming that there is a contractual duty of good faith and fair dealing in the broker-customer relationship that includes the duty to adhere to established industry or regulatory norms, including SEC and SRO rules. My sense is that whatever principles are articulated by the SEC will have high potency.

Therefore, the Commission should worry about excessive indeterminacy, and given the awkwardness of applying blanket fiduciary norms to broker sales activity, leaving the rule too open-ended is probably unfair and inefficient. What I would envision is a set of somewhat more textured rules that apply to both brokers and advisers on each of the crucial aspects of the advisory relationship.

For instance, take the matter of conflicts of interest. The general principle is that no broker or adviser should recommend to a customer or client any security or investment because of the profits gained or losses avoided that the sale would generate for him or his firm. The SEC could, of course, leave it at that. But the interpretive questions are self-evident and cry out for answers. In a public offering, for example, underwriters and dealers have special incentives to fill and sell-out their allotments. Is it wrong to recommend a new offering, then? (If so, it would probably be the end of the book-building process. ${ }^{48}$ ) What about an in-house mutual fund, or a municipal bond in which a firm might have a particularly large inventory?

The SEC should answer such questions, and as suggested earlier, I doubt that the case has been made for an outright ban on all such conflicts. The better response is two-fold: some prophylactic regulation of the process by which brokers (and advisers) are rewarded, so as to make the conflicts less acute, and an effort at more effective disclosure of any residual conflicts. As to the former, as I suggested earlier as well, having the firm itself describe for the SEC its own reasonable plan for minimizing the internal pressures (and 
thereafter adhere to, or be punished) is probably better than a "one size fits all" rule. As to the latter, the rule cannot be too specific, because there are so many kinds of conflict. On the other hand, some guidance is appropriate precisely because the brokerage business is sufficiently complex that one can always think of subtle conflicts - e.g., is a broker required to disclose that he is well behind on his monthly or annual quota, and thus motivated to press his customers too hard? What about discretionary bonus programs for top producers that are based on firm or branch profitability?

There are no easy or perfect answers, of course. My only point is that an open-ended broker fiduciary obligation is so loaded with unanswered questions that baseline predictability would come slowly, if at all. The SEC and FINRA can do better, but only by venturing deeply into the thicket and building a platform that offers investors better protection from what lies beneath. However challenging this might seem, decisions about the proper design of this platform deserve to be made publicly and explicitly through rule-making. Simply placing the fiduciary label on the securities industry and leaving the rest to ad hoc decisions will produce a platform that is neither stable nor functional. 